possible because so much more experimental work is required before the reactions discussed by the author can be properly understood and correlated. $\mathrm{He}$ would probably have been wise to make less ambitious claims for his book, and to put it forward as a record of what is known about zirconium compounds, recognizing the limitations that are imposed by writing at this relatively early stage in the development of the subject.

A. G. Quarrell

\section{EVOLUTIONARY THEORY AFTER MENDEL}

Genetics and Twentieth Century Darwinism

(Cold Spring Harbor Symposia on Quantitative Biology, Vol. 24.) Pp. xv + 321. (Cold Spring Harbor, New York: Long Island Biological Association, 1959.) 8 dollars.

$\mathrm{B}$ ETWEEN an introduction by E. Mayr, surveying the contemporary aspects of evolution, selection and speciation and a concluding synthesis by G. L. Stebbins, which is partly based on the twenty-two contributions by the participants in the symposium, this volume contains a good deal of factual information from many fields. While the general and qualitative conclusions of the specialists are on the whole remarkably uniform and furthermore similar to concepts which Darwin himself held a century ago, one is struck by the vastly greater extent and certainty of our knowledge and also by the superior techniques and quantitative methods which are employed in gaining this knowledge.

The only fundamental difference between our approach and that of Darwin stems from our recog. nition of particulate and chromosomal inheritance as the basis of much of hereditary variability upon which selection and isolation act; and thus mutation and gene recombination--processes of which Darwin was of necessity ignorant-play very prominent parts in our ideas of evolution. Genes as raw materials of evolution are considered by Dobzhansky, Stubbe and Buzzati-Traverso, while race formation by selection is described by Morley and by Schwanitz in plants, by Mourant (blood groups), Barnicot (climatic influences) and Coon (other ecological factors) in man and by Lamotte in snails. Genetical conditions conducive or refractory to race formation are described by Carson. The interplay between ecology and genetics in the evolution of mimicry is expounded by Sheppard; the differentiation-hybridization eycle and polyploidy in Achillea by Ehrendorfer.

Speciation and isolation are described by Kitzmiller and Laven in mosquitoes and by Baker concerning flowering plants. Wallace analyses the influence of genetical systems on geographical distribution.

In addition to those contributions, which deal with evolutionary processes still at work, there are four papers concerning the fossil record and evolutionary rates in early vascular plants (Andrews), mammals (Kurten), fossil (Heberer) and contemporary (Hunt) man. A final rather heterogeneous group of papers, headed "Trends of Evolution", deals with the nature and origin of supraspecific taxa (Simpson), the chromosome evolution in the Australian flora and the progress in the brain and sense organs of animals (Rensch).
As usual in the Cold Spring Harbor series, the individual papers are followed by selections from the discussions in which, in addition to the contributors, a wider circle of listeners participated.

Like its predecessor on the "Origin and Evolution of Man" (1950) the present symposium included geneticists, anthropologists and palæontologists, to which, however, ecologists were added. This fourfold attack resulted in a broader grasp of the subject of evolution : in revealing the existence of considerable gaps and blurs between the deseriptions it also shows where further work is needed.

The volume is well produced, illustrated and documented, and I have noticed only one editorial mistake : a completely wrong title in the contents of the paper on p. 115.

H. Kalmus

\section{THE EXPLODING WIRE PHENOMENON}

\section{Exploding Wires}

Based on Conference on the Exploding Wire Phenomenon, April, 1959, conducted by Geophysics Research Directorate, Air Force Cambridge Research Center, with the co-operation of Lowell Technological Institute Research Foundation. Edited by William G. Chace and Howard K. Moore. Pp. 373. (New York: Plenum Press, Inc.; London : Chapman and Hall, Ltd., 1959.) 76s. net.

CURRENT interest in thermonuclear projects, in 1 high-speed photography, and in phenomena associated with shock waves has provided a powerful stimulus to research on exploding wire phenomena. It is a disappointment to find that the first book on this subject, described by the publishers as a significant monograph, is only a collection of papers presented at a conference, with no index, no record of the discussions, and the minimum of introduction. Apart from the stiff binding and the high quality of the illustrations, the arrangement of the material which has been adopted, putting the diagrams at the end of each paper, and the photographic reproduction of the text, cause this volume to resemble the preprint of a conference rather than an authoritative work.

Some of the papers presented are excellent; but the general emphasis is on experimental methods rather than on results. Roughly half the twenty-five papers presented deal with the use of techniques such as voltage and current oscillography, high-speed photography and radiometry in studying the explosion of wires by condensers storing energies between one and one million joules. Of particular interest are papers dealing with the 'dwell time' between the initial current pulse and the build-up of the main discharge, and Scherrer's elegant work with a water-dielectric condenser. The remainder of the volume is evenly divided between theory and application. In the former category there are three useful papers on cylindrical shock waves; the applications include flash sources for photochemistry, the bonding of nonconductors, plasma acceleration, and as fuses to protect condenser banks.

While this volume will be of value to workers in the field, it is neither sufficiently correlated nor comprehensive enough to be a good, balanced account of the subject. It would have been greatly improved by the inclusion of a long introduction describing the previous 